\title{
HISTOPATHOLOGIC FINDINGS IN WOMEN UNDERGOING HYSTEROSCOPIC RESECTION OF ENDOMETRIAL POLYPS AND UTERINE MYOMAS
}

\author{
Hrvojka Soljačić Vraneš ${ }^{1}$, Ivka Djaković ${ }^{1}$, Marija Vrljičak ${ }^{2}$, Nives Đurić Orsag ${ }^{1}$, \\ Krunoslav Kuna ${ }^{1}$, Zdenko Kraljević ${ }^{1}$, Tanja Leniček ${ }^{3}$ and Ivan Brlečić ${ }^{1}$
}

${ }^{1}$ Department of Gynecology and Obstetrics, Sestre milosrdnice University Hospital Centre, Zagreb, Croatia;

${ }^{2}$ School of Medicine, University of Rijeka, Rijeka, Croatia;

${ }^{3}$ Ljudevit Jurak Department of Pathology, Sestre milosrdnice University Hospital Centre, Zagreb, Croatia

\begin{abstract}
SUMMARY - The aim of our study was to determine the prevalence of endometrial premalignant and malignant lesions in women undergoing hysteroscopy and to identify anthropologic factors related to the presence of malignancy. Data on 3470 women with submucosal myomas or endometrial polyps suspected on ultrasound were retrospectively analyzed. Hysteroscopy was performed in all these women in order to make a more precise diagnosis. Histologic analysis of endometrial samples obtained during hysteroscopy was used to confirm the diagnosis. Statistical analysis was performed using the SPSS 20.0.0 software. The mean age of study women was $49.1 \pm 13.3$ years. The number of procedures performed due to the referral diagnosis of endometrial or submucosal myoma significantly increased over the 16-year study period. A significantly higher number of women had a benign histopathologic diagnosis. Histologic analysis revealed malignancy in 67 women. The youngest woman and oldest woman with malignant findings was aged 32 and 75, respectively. A significantly higher number of women with atypical hyperplasia and malignancy were in menopause. A comparable number of women with different histologic findings lived in urban and rural areas. There were a significantly larger proportion of widows among women with the histologic diagnosis of atypical hyperplasia or malignancy. The prevalence rate of malignancy in women having undergone hysteroscopy for polyps and myoma found by ultrasound was $1.93 \%$. Postmenopausal status and older age were associated with an increased risk of malignancies, but premalignant changes and malignancies were also found in young and premenopausal women. Therefore, diagnostic hysteroscopy can be recommended in women of all age groups.
\end{abstract}

Key words: Polyps; Myoma; Ultrasonography; Uterine neoplasms; Female; Hysteroscopy

\section{Introduction}

Theoretically, the beginnings of hysteroscopy may be traced back to the beginning of the $19^{\text {th }}$ century with construction of the first instrument that used a mirror to reflect candle light and direct it through a tube into the uterine cavity to illuminate it for obser-

Correspondence to: Ivka Djaković, Department of Gynecology and Obstetrics, Sestre milosrdnice University Hospital Centre, Vinogradska c. 29, HR-10000 Zagreb, Croatia

E-mail: ivkadj@yahoo.com

Received October 4, 2018, accepted November 19, 2018 vation $^{1}$. In the next decades, various technical problems had to be solved before it became possible to properly visualize the intrauterine pathology. Thus, in the second half of the $20^{\text {th }}$ century, hysteroscopy became a more widely used method.

Today, hysteroscopy is an essential method for the treatment of intrauterine pathology. Indications for diagnostic and therapeutic hysteroscopy include all endometrial and subendometrial disorders. Frequently, diagnostic hysteroscopy is used for visualization of endometrial pathology in cases of prolonged or abnormal bleeding or in cases where pathology within the uter- 
ine cavity was revealed by ultrasound. In such cases, diagnostic hysteroscopy usually includes collecting samples for histologic analysis and becomes a treatment method in cases where myomas or polyps are clearly visualized.

Although the pathogenesis of endometrial polyps has not been completely elucidated, they are considered a localized hyperplasia of the endometrium, originating from the endometrial basal layer. Polyps affect women of all age groups, usually those between 40 and 60 years of age ${ }^{2}$. Patients with polyps may be without symptoms or they may have irregular bleeding, heavy or prolonged menstrual periods or postmenopausal bleeding, endometritis, pain, and possible infertility ${ }^{3,4}$. Polyps are often associated with tamoxifen treatment ${ }^{5}$. They are usually benign, but histopathologic analysis sometimes reveals they harbor atypical hyperplasia or even cancer ${ }^{6,7}$.

The aim of our study was to determine the prevalence of endometrial premalignant and malignant lesions in women undergoing hysteroscopy at the Sestre milosrdnice University Hospital Centre in Zagreb, Croatia, over a 16-year period and to identify anthropological factors related to the presence of malignancy.

\section{Patients and Methods}

A retrospective study was performed at Sestre milosrdnice University Hospital Centre in Zagreb, Croatia, to identify the risk of malignancy in women with ultrasound-diagnosed endometrial polyps or myomas from January 1, 2000 until December 31, 2015. All patients in whom hysteroscopy was planned in the investigated period underwent transvaginal sonography for assessment of intrauterine pathology. In 3470 of them, submucosal myomas or endometrial polyps were suspected on ultrasound. Hysteroscopy was performed in all of these women in order to make a more precise diagnosis. Histologic analysis of endometrial samples obtained during hysteroscopy was used to confirm the diagnosis.

According to their menopausal status, the women were divided into two groups of postmenopausal and premenopausal women. According to the place of residence, the women were divided into those living in urban and those living in rural areas. According to their marital status, the women were divided into four groups as follows: married or living with partner, single, divorced, and widowed.

\section{Statistical analysis}

The $\chi^{2}$ was used to test difference in the prevalence of medical conditions in particular groups. Analysis of variance (ANOVA) was performed to test age difference according to diagnosis and different time periods. Post-hoc Tukey HSD test was used, as appropriate, to determine difference between the groups. To determine the sensitivity and specificity of suspected diagnoses, an online VassarStats calculator was used (http://www.vassarstats.net/). The level of statistical significance was set at $\mathrm{p}<0.05$ for all analyses. Statistical analysis was performed using the SPSS 20.0.0 software (IBM Corp., Armonk, NY, USA).

\section{Results}

There were 3470 women included in the study from 2000 to 2015. All women were hospitalized at the Sestre milosrdnice University Hospital Centre for scheduled hysteroscopy.

After preoperative examination, all women underwent transvaginal ultrasound assessment on the day before hysteroscopy. The women suspected of having endometrial polyp or submucosal myoma on preoperative ultrasound examination were included in the study. The mean age of women was $49.1 \pm 13.3$, range 20-84 years.

The number of procedures performed due to referral diagnosis of endometrial polyp $\left(\chi^{2}(15, \mathrm{~N}=2945)=\right.$ $1871.34, \mathrm{p}<0.001)$ or submucosal myoma $\left(\chi^{2}(15\right.$, $\mathrm{N}=525)=222.18, \mathrm{p}<0.001)$ significantly increased over the 16-year study period (Fig. 1).

A tissue sample for histopathologic analysis was obtained intraoperatively in all women.

Significantly more women had a benign histopathologic diagnosis $\left(\chi^{2}(3, \mathrm{~N}=3470)=8761.1, \mathrm{p}<0.001\right)$ (Fig. 2).

Malignancy was found by histologic analysis in 67 women, i.e. $1.93 \%$ of all women included in the study. Among 67 malignant samples, 66 were adenocarcinomas and one was sarcoma; 62 adenocarcinomas were found in women with suspected polyps on ultrasound, and 4 adenocarcinomas and one sarcoma were found in women in whom myomas were suspected on ultrasound.

The mean age of women with benign histologic findings, non-atypical hyperplasia, or atypical hyper- 


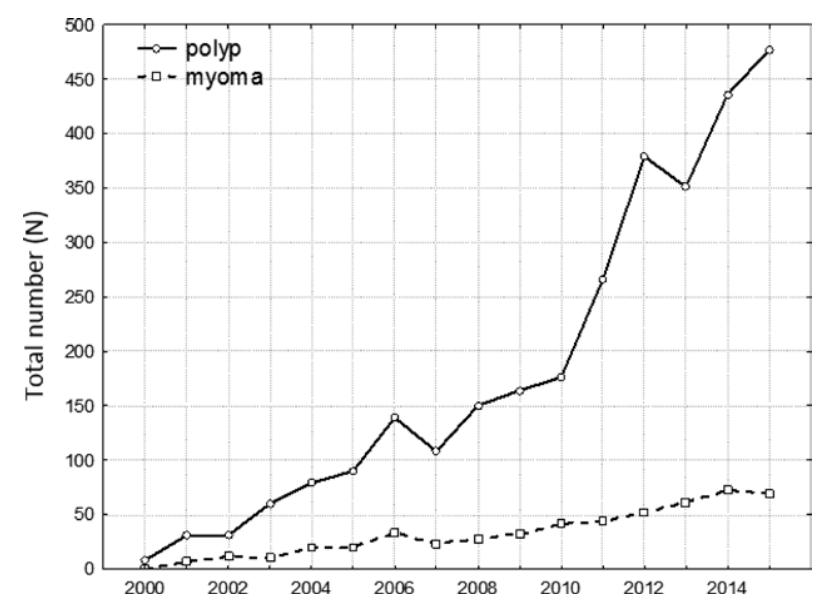

Fig. 1. Number of hysteroscopies due to endometrial polyp or submucosal myoma.

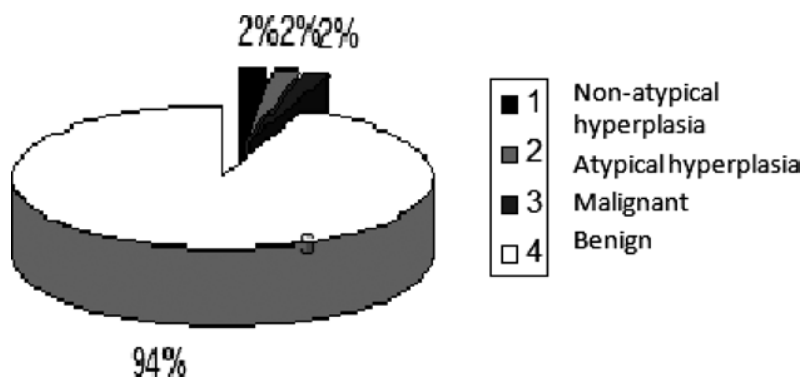

Fig. 2. Percentage of women with different histologic findings.

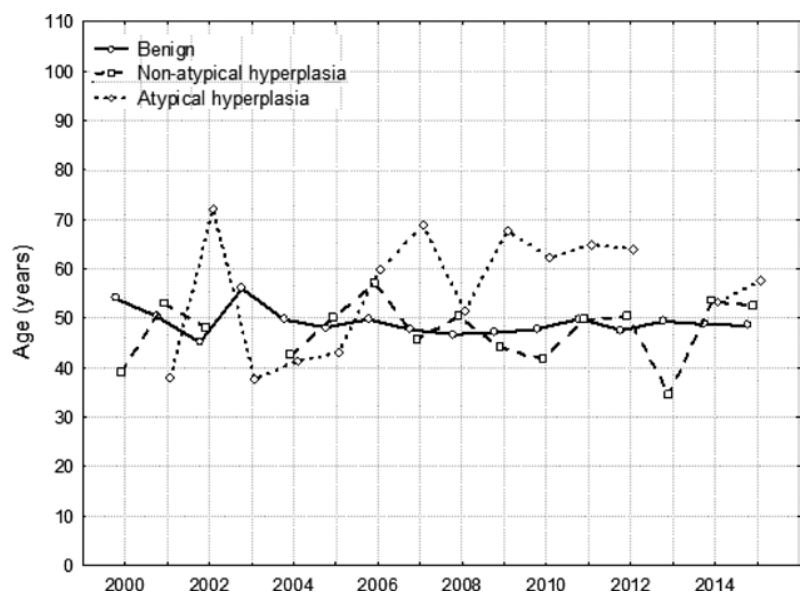

Fig. 3. Mean age of women with different histologic findings in the 2000-2015 period.

plasia is shown in Figure 3. Due to insufficient data on cancer in each category and for each year, analysis could not be performed. The youngest woman with malignant finding was aged 32 and the oldest 75 years.

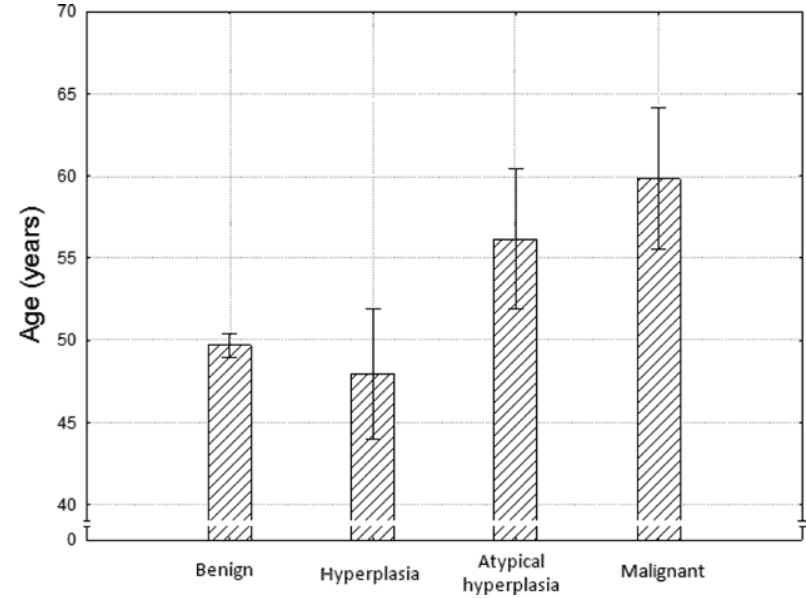

Fig. 4. Mean age of women with different histologic findings.

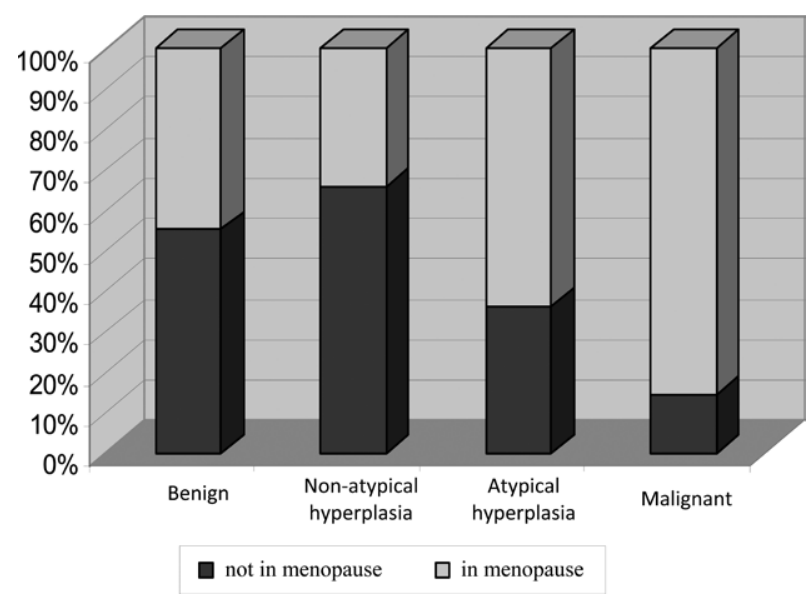

Fig. 5. Proportion of women in menopause according to histologic findings.

Women with different histologic findings differed significantly in age $(\mathrm{F}(3,3448)=21.09, \mathrm{p}<0.001)$ (Fig. 4). Post-hoc Tukey HSD test showed that women with histologic evidence of atypical hyperplasia or malignancy were significantly older in comparison with women with benign histologic findings and non-atypical hyperplasia.

With respect to menopausal status, significantly more women with atypical hyperplasia and malignancy were in menopause in comparison to women with benign histologic findings or non-atypical hyperplasia $\left(\left(\chi^{2}(3, N=3470)=60.71, \mathrm{p}<0.001\right)\right.$ Fig. 5$)$.

A similar number of women with different histologic findings lived in urban and rural areas, i.e. there were no differences in the prevalence of diagnoses be- 
tween these two groups of women $\left(\chi^{2}(3, \mathrm{~N}=3660)=3.2\right.$, $\mathrm{p}>0.05$ )

There was a significantly larger proportion of widows among women with histologic diagnosis of atypical hyperplasia or malignancy than among women with benign histologic findings and non-atypical hyperplasia $\left(\chi^{2}(9, \mathrm{~N}=3470)=29.2, \mathrm{p}<0.01\right)$.

\section{Discussion}

Hysteroscopy is the most frequently performed procedure in women of childbearing age. Indications for hysteroscopy most often include bleeding disorders (heavy, prolonged, irregular or scarce bleeding); suspected submucosal myoma; endometrial polyps; developmental uterine anomalies; intrauterine adhesions; suspected hyperplasia or endometrial cancer; intrauterine foreign body, and so on ${ }^{8}$.

Submucosal myomas very often protrude into the uterine cavity and usually cause heavy and prolonged menstrual bleeding, often leading to anemia. It is, therefore, an indication for hysteroscopic myomectomy'.

Endometrial polyps may be solitary or diffuse, small or so large as to fill the entire uterine cavity, pushing through and dilating the cervical canal, and bulging out of the external orifice. In principle, such polyps are benign, but sometimes they may harbor hyperplasia or even a cancer ${ }^{10-12}$. Therefore, many authors recommend their surgical removal ${ }^{13}$. Endometrial hyperplasia is proliferation of the glands of different sizes and shapes, characterized by an increased glands-to-stroma ratio. Hyperplasias may be classified into atypical and nonatypical. Based on their structural abnormalities, they are divided into simple and complex hyperplasias ${ }^{14}$. Approximately $2 \%$ of non-atypical hyperplasias progress to cancer, as opposed to atypical hyperplasias, which progress to cancer in $23 \%-25 \%$ of cases ${ }^{15,16}$.

In our study, histologic analysis of tissue samples collected during hysteroscopy in our patients showed non-atypical hyperplasia in $2.22 \%$, atypical hyperplasia in $2.05 \%$, and malignancy in $1.93 \%$ of cases. The prevalence of histologically confirmed malignancy in our study was similar to that reported in the literature ${ }^{17,18}$. Hyperplasia has been reported to be present in polyps in different percentages, ranging from $1.3 \%$ to $13.5 \%$. These percentages mostly refer to non-atypical hyperplasia, whereas atypical hyperplasia is found at a substantially lower frequency ${ }^{18,19}$.
In our patients, we found significant age differences according to their diagnoses, i.e. women with benign findings including non-atypical hyperplasia were significantly younger than those with atypical hyperplasia or malignancy. Other authors report similar findings ${ }^{17,18}$.

Since menopausal status is usually associated with older age, our results showing a statistically significant association between age and atypia or malignancy were not surprising. These findings are in line with those reported by other authors ${ }^{20}$.

We found no significant difference in the prevalence of histologic diagnoses in our patients with respect to their place of residence, i.e. between women living urban versus rural areas.

A significantly greater number of widows were found in the group of women with atypical hyperplasia and malignancy as compared with the group of women with benign findings and non-atypical hyperplasia. This difference could be attributed to the fact that widows were mostly women of older age.

\section{Conclusion}

The prevalence of malignancy in women having undergone hysteroscopy for polyps and myoma found by ultrasound was $1.93 \%$. Postmenopausal status and older age were associated with an increased risk of malignancies, but premalignant changes and malignancies were also found in young and premenopausal women. Therefore, diagnostic hysteroscopy may be recommended in women of all age groups.

\section{References}

1. Bozzini P. Lichtleiter: Ein Efingung zur Anschauung innere Teile und Krankenheiten. J Prakt Heilkd. 1806;24:107. (in German)

2. Sherman ME, Mazur MT, Kurman RJ. Benign diseases of the endometrium. In: Kurman RJ, editor. Blaustein's Pathology of the Female Genital Tract. $5^{\text {th }}$ edn. New York: Springer-Verlag, 2002;421-66.

3. Reslova T, Tosner J, Resl M, Kugler R, Vavrova I. Endometrial polyps. A clinical study of 245 cases. Arch Gynecol Obstet. 1999;262:133-9. http://dx.doi.org/10.1007/s004040050241.

4. Dallenbach-Hellweg G. The endometrium of infertility. A review. Pathol Res Pract. 1984;178:527-37. http://dx.doi. org/10.1016/S0344-0338(84)80084-9.

5. Corley D, Rowe J, Curtis MT, Hogan WM, Noumoff JS, Livolsi VA. Postmenopausal bleeding from unusual endome- 
trial polyps in women on chronic tamoxifen therapy. Obstet Gynecol. 1992;79:111-6.

6. Salm R. The incidence and significance of early carcinomas in endometrial polyps. J Pathol. 1972;108:47-53. http://dx.doi. org/10.1002/path.1711080106.

7. Wolfe SA, Mackles A. Malignant lesions arising from benign endometrial polyps. Obstet Gynecol. 1962;20:542-50.

8. Neis KJ, Brander P, Hepp H, editor. Hysteroscopy. Stuttgart-New York: Georg Theime Verlag, 1994;18-34.

9. Fernandez H, Kadoch O, Capella-Allouc S, Gervaise A, Taylor S, Frydman R. Hysteroscopic resection of submucous myomas: long term results. Ann Chir. 2001;126:58-64. http://dx.doi. org/ 10.1016/s0003-3944(00)00458-2.

10. Silva EG, Jenkins R. Serous carcinoma in endometrial polyps. Mod Pathol. 1990;3:120-8.

11. Gambadauro P, Martínez-Maestre MÁ, Schneider J, Torrejón R. Malignant and premalignant changes in the endometrium of women with an ultrasound diagnosis of endometrial polyp. J Obstet Gynaecol. 2014;34:611-5. http://dx.doi.org/10.3109/0 1443615.2014.916255.

12. Pettersson B, Adami H-O, Lindgren A, Hesselius I. Endometrial polyps and hyperplasia as risk factors for endometrial carcinoma. A case-control study of curettage specimens. Acta Obstet Gynecol Scand. 1985;64:653-9. http://dx.doi.org/10.3109 /00016348509158208

13. Lieng M, Istre O, Qvigstad E. Treatment of endometrial polyps: a systematic review. Acta Obstet Gynecol Scand. 2010; 89(8):992-1002. http://dx.doi.org/10.3109/00016349.2010.49 3196.
14. Scully RE, Bonfiglio TA, Kurman RJ, Silverberg SG, Wilkinson EJ. Histologic Typing of Female Genital Tract Tumors (International Histological Classification of Tumors). $2^{\text {nd }}$ edn. New York: Springer-Verlag, 1994.

15. Kurman RJ, Kaminski PF, Norris HJ. The behavior of endometrial hyperplasia. A long-term study of "untreated" hyperplasia of 170 patients. Cancer. 1985;56:403-12. http://dx.doi.org/ 10.1002/1097-0142(19850715)56:2<403::aid-cncr28205602 $33>3.0 . \operatorname{co} ; 2-\mathrm{x}$.

16. Ferenczy A, Gelfand M. The biologic significance of cytologic atypia in progesterone-treated endometrial hyperplasia. Am J Obstet Gynecol. 1989;160:126-31. http://dx.doi.org/10.1016/ 0002-9378(89)90103-8.

17. Costa-Paiva L, Godoy CE Jr, Antunes A Jr, Caseiro JD, Arthuso M, Pinto-Neto AM. Risk of malignancy in endometrial polyps in premenopausal and postmenopausal women according to clinicopathologic characteristics. Menopause. 2011;18: 1278-82. http://dx.doi.org/10.1097/gme.0b013e31821e23a1.

18. Antunes A Jr, Costa-Paiva L, Arthuso M, Costa JV, PintoNeto AM. Endometrial polyps in pre- and postmenopausal women: factors associated with malignancy. Maturitas. 2007; 57:415-21.http://dx.doi.org/10.1016/j.maturitas.2007.04.010.

19. Wethington SL, Herzog TJ, Burke WM, Sun X, Lerner JP, Lewin SN, Wright JD. Risk and predictors of malignancy in women with endometrial polyps. Ann Surg Oncol. 2011;18: 3819-23. http://dx.doi.org/ 10.1245/s10434-011-1815-z.

20. Lee SC, Kaunitz AM, Sanchez-Ramos L, Rhatigan RM. The oncogenic potential of endometrial polyps: a systematic review and meta-analysis. Obstet Gynecol. 2010;116:1197-205. http: //dx.doi.org/ 10.1097/AOG.0b013e3181f74864.

\section{PATOHISTOLOŠKI NALAZI KOD ŽENA PODVRGNUTIH HISTEROSKOPSKOJ RESEKCIJI ENDOMETRALNIH POLIPA I MIOMA MATERNICE}

\section{H. Soljačić Vraneš, I. Djaković, M. Vrljičak, N. Đurić Orsag, K. Kuna, Z. Kraljević, T. Leniček i I. Brlečić}

Cilj ove studije bio je odrediti učestalost endometralnih premalignih i malignih lezija nakon histeroskopije te identificirati antropološke čimbenike povezane s malignitetom. Retrospektivno su analizirani podaci za 3470 žena s ultrazvučnom sumnjom na submukozni miom ili endometralni polip. Svim ženama je učinjena histeroskopija kako bi se dobila precizna dijagnoza. Uzorci iz endometrija dobiveni histeroskopijom poslani su na histološku analizu. Statistička analiza učinjena je primjenom programa SPSS 20.0.0. Prosječna dob žena u studiji bila je 49,1 $\pm 13,3$ godine. Broj zahvata zbog uputne dijagnoze endometralnog ili submukoznog mioma značajno je porastao u šesnaestogodišnjem razdoblju trajanja studije. Značajno veći broj žena imao je benignu histopatološku dijagnozu. Histološka analiza pokazala je malignitet u 67 žena. Najmlađa i najstarija žena s malignitetom imale su 32 i 75 godina. Značajno veći broj žena s atipičnom hiperplazijom i malignitetom bio je u menopauzi. Usporediv broj žena s različitim histološkim nalazima živio je u urbanim i ruralnim sredinama. Bio je značajnije viši udio udovica s dijagnozom atipične hiperplazije ili maligne bolesti. Učestalost malignosti kod žena kojima je učinjena histeroskopija zbog ultrazvučnog nalaza mioma ili polipa bila je 1,93\%. Menopauza i starija dob bile su povezane s povišenim rizikom za zloćudne bolesti, ali premaligne i maligne promjene nađene su i kod mladih i premenopauzalnih žena. Stoga se dijagnostička histeroskopija preporuča u svim dobnim skupinama.

Ključne riječi: Polipi; Miom; Ultrasonografija; Uterini tumori; Ženska osoba; Histeroskopija 